\title{
Comparative assessment of widespread irrigation with low quality mine-water in undisturbed and rehabilitated mine-lands in the upper Olifants using the ACRU2000 model
}

\author{
OA Idowu ${ }^{4 *}$, SA Lorentz², JG Annandale ${ }^{3}$, M Aken $^{4}$, MP McCartney ${ }^{5}$, \\ SLC Thornton-Dibb ${ }^{2}$ and A Westhuizen ${ }^{6}$ \\ ${ }^{1}$ Department of Water Resources Management and Agrometeorology, University of Agriculture, P.M.B. 2240, Abeokuta, Nigeria \\ ${ }^{2}$ School of Bioresources Engineering and Environmental Hydrology, University of KwaZulu-Natal, Private Bag X01, \\ Scottsville, Pietermaritzburg, South Africa \\ ${ }^{3}$ Department of Plant Production and Soil Science, University of Pretoria, Pretoria 0002, South Africa \\ ${ }^{4}$ Anglo Coal Environmental Services, South Africa \\ 5International Water Management Institute Sub-Regional Office, PO Box 5689, Addis Ababa, Ethiopia \\ ${ }^{6}$ Institute for Commercial Forestry Research, University of KwaZulu-Natal, Pietermaritzburg, South Africa
}

\begin{abstract}
The $A C R U$ agrohydrological model, in the form of ACRU2000 and its salinity module, ACRUSalinity, was employed in catchment-scale assessment of widespread irrigation with low quality mine-water in undisturbed (un-mined) and rehabilitated soils in the Upper Olifants basin of South Africa. The study area comprised a small catchment of $4.7 \mathrm{~km}^{2}$ located in a coal-mine environment, known as the Tweefontein Pan catchment. The catchment drained to a surface reservoir (Tweefontein Reservoir) of maximum capacity and surface area $4000 \mathrm{M} \ell$ and $1.5 \mathrm{~km}^{2}$, respectively. The catchment was instrumented to measure hydrodynamic responses and simulated as a hydrological system. Consideration was given to runoff, groundwater storage, evapotranspiration, baseflow, interception, irrigation water supply and rainfall, thereby accounting for all the dominant hydrological components of the system. Three scenarios were simulated using the available records for 5 years (1999 to 2004). The first was a baseline scenario representing the prevailing condition in the study area and the other 2 scenarios represented widespread irrigation with the mine-water on undisturbed and rehabilitated soils. In simulating the widespread irrigation on rehabilitated soils, a distinction was made between a rehabilitated irrigated area before and after the re-establishment of the equilibrium water table. Comparison of the results from the simulated scenarios indicated that a greater undisturbed area (max of $160 \mathrm{ha}$ ) than rehabilitated area (max of $120 \mathrm{ha}$ ) could be irrigated with mine-water from the Tweefontein Reservoir. Irrigation on rehabilitated soils depleted the water in the reservoir more rapidly than irrigation on undisturbed soils, due to lower runoff and higher ingress to groundwater in rehabilitated areas.
\end{abstract}

Keywords: mine-water, widespread irrigation, mined land irrigation, Upper Olifants, catchment scale, hydrological assessment, $A C R U 2000$

\section{Introduction}

A large amount of low quality mine-water is generated by the coal mines in South Africa. In the Mpumalanga coalfields and the Olifants Basin, for example, estimates of $360 \mathrm{M} \ell / \mathrm{d}$ and $170 \mathrm{M} / \mathrm{d}$, respectively, may be generated after the closure of the mines there (Grobbelaar et al., 2004). The general problem of the disposal of the generated low quality mine-water has been well recognised in South Africa (DWAF, 1993; Pulles et al., 1995; Bell et al., 2001; Younger, 2002; Coleman et al., 2003; Heath et al., 2004). The need for a cost-effective as well as environmentally sustainable means of mine-water disposal has fostered interest in the possibility of utilising mine-water for irrigation in suitable soils, which could include rehabilitated mined land. The potential offered by such mine-water utilisation will, however, depend on the availability of the water in proximity to a suitable soil (Tanner et al., 1999). Other factors

\footnotetext{
* To whom all correspondence should be addressed.

욜 +234-805-257-7235;

e-mail: olufemidowu@gmail.com

Received 22 July 2008; accepted in revised form 5 October 2010.
}

that need to be considered are the resultant soil water and salt balance for different cropping systems, the choice of irrigation management strategies (Jovanovic et al., 2001), and the impact of the irrigation drainage water on water resources. The focus of this study was the impact of mine-water irrigation on water resources.

The use of wastewater from collieries for irrigation of agricultural crops on both undisturbed (i.e. un-mined) and rehabilitated soils has been investigated in some detail in South Africa (Du Plessis, 1983; Barnard et al., 1998; Annandale et al., 1999; Annandale et al., 2001; Annandale et al., 2002; Jovanovic et al., 2002). These investigations focused on field assessments (at centre pivot scale) of the impacts of irrigation with minewater on crop production, soil characteristics and the quantity and quality of drainage water. Rehabilitated soils are different from normal agricultural soils (Viljoen, 1992; Schoeman et al., 2002). Rehabilitation is carried out after complete removal of the overburden and the coal. The material from an adjacent strip (a mixture of broken rock and soft overburden) is back-filled into the void and graded to form a new surface topography. Usable topsoil, stripped ahead of the mining, is then replaced on the new surface. Because of the large soil volumes involved, heavy machinery is required and this exerts 
a considerable compactive force on the soil over which it travels. Various soil amelioration and re-vegetation operations then follow on the re-established land surface to complete the rehabilitation process.

The availability of rehabilitated soils in the mining environment, where a large amount of low quality mine-water is also available, could make such soils targets for widespread irrigated agriculture, using the available low quality minewater. Field studies have shown that there is a high potential for using mine-water in raising certain agricultural crops (Annandale et al., 2002; Jovanovic et al., 2002). However, the studies need to be extended beyond field scale, and impacts of large-scale irrigation with mine-water on both surface water and groundwater resources need to be assessed. Such an assessment would make the impact from large-scale utilisation of mine-water for irrigation, on both undisturbed and rehabilitated soils, predictable and comparable. In addition, it will enable design of adequate policies and institutional arrangements that can guarantee more effective planning and management of water resources. In a recent study, Annandale et al. (2006) evaluated the potential impact of irrigation with mine-water on the groundwater of sub-areas west of Witbank, using the numerical modelling package FEFLOW (Diersch, 1988). Results from field-scale studies were used as inputs. In addition to the fact that the study was not based on a catchment, it focused on direct recharge to groundwater only. Effective water resource assessment and management, however, is best considered at catchment scales (Global Water Partnership, 2000), taking into consideration the land uses and all the essential components of the hydrological cycle. Such a consideration enables an integrated assessment of water resources in the different components of a hydrological system. Furthermore, it facilitates a broader planning and management programme with a wider context, which includes downstream stakeholders. The objective of this study, therefore, was to use a catchment as the basis for comparing the impact of widespread irrigation of undisturbed and rehabilitated soils, using mine-water, on the water resources of parts of the Upper Olifants basin. It aimed at the integrated assessment of the volume of water and the mass of salt in the different components of the hydrological system in the catchment. The study employed the $A C R U$ agrohydrological model, in the form of updated $A C R U 2000$ and its salinity module, ACRUSalinity, for mine land.

\section{The $A C R U$ agrohydrological model}

The $A C R U$ agrohydrological model is a multi-purpose, daily time step, physical conceptual model that integrates the various water-budgeting and runoff-producing components of the terrestrial hydrological system (Schulze et al., 1995a). It is structured to be sensitive to land cover/use and climate changes and its water budgeting is responsive to supplementary watering by irrigation, inflows, and abstractions. The model can operate either as a lumped small catchment model or as a distributed cell-type model for larger catchments or in areas of complex land use and soils. Water input into the hydrologic system occurs as precipitation or irrigation. In the case of surface reservoirs, inflows, abstractions and evaporation take place. Vegetative or impervious land covers may intercept part or all of the water input. The rainfall and/or irrigation not abstracted as interception or as stormflow (either rapid response or delayed) first enters the soil profile through a surface layer and then resides in the topsoil (A) horizon. When the drained upper limit of the topsoil is reached, excess water percolates into the subsoil (B) horizon asdrainage at a rate dependent on the respective horizon soil textural characteristics, wetness, and drainage-related properties. Saturated and unsaturated soil water redistribution may take place between soil horizons. However, soil water movement downwards from the lower (B) soil horizon drains into the groundwater storage, from where baseflow may be generated. Baseflow release from the groundwater store is based on a response coefficient, which acts as a decay constant and is intrinsically dependent on factors such as groundwater storage volume, geology, catchment area and slope. Unlike in a non-irrigated area where the subsurface soil-water redistribution takes place between 2 soil horizons (A and B), in the irrigated area, this takes place in only 1 soil horizon. The soil horizon in the irrigated area is assumed to be a tilled soil. It is defined as the zone in which the majority of roots occur, and therefore, where the amount of water available in the soil is regulated (Lecler and Schulze, 1995). Due to repeated tillage, this zone is assumed homogenous, so that differentiation into horizons $\mathrm{A}$ and $\mathrm{B}$ was considered unnecessary. The depth of this zone can be stipulated by the $A C R U$ user. Evaporation takes place from the intercepted water and from the various soil horizons, in which case it is either split into separate components of soil-water evaporation and plant transpiration, or combined as total evaporation. Plant transpiration takes place from all root-active soil horizons.

In this study, the $A C R U$ Agrohydrological model was employed in the form of ACRU2000, which is the objectoriented version of the model, written in the Java programming language (Clark et al., 2001). ACRUSalinity is the hydrosalinity module of $A C R U 2000$ and it inherits the basic structures and flow configuration of $A C R U 2000$ (Teweldebrhan et al., 2003). The internal computations of the hydrosalinity processes in ACRUSalinity involve salt load (mg) in terms of the total dissolved solids (TDS). Hence, ACRUSalinity determines the conservative salt load in different components of a hydrologic system and not the different solute species concentrations. The salt load of the subsurface layers is replenished from internal and external sources. The salt load of the A horizon is replenished from rainfall salt input and irrigation water, whereas in the case of the B horizon and groundwater store, it is replenished by the salt load added from the overlying layer along with the percolating water. The model allows the generation of an internal source of salt load to a particular soil horizon or groundwater store through salt dissolution from the geology of the soil horizon or the aquifer in which the groundwater is stored. The salt-generating process is based on first-order rate kinetics proposed by Ferguson et al. (1994). If the salinity of a soil layer is greater than the specified maximum concentration, then the excess salt load is precipitated. ACRUSalinity enables the assessment of the salt load transport in subsurface components and runoff, as well as the allocation of the runoff salt load to various destination components within a land segment area. It could, therefore, deal with the salt load transport in dry land and irrigated conditions, in reservoirs and channel reaches, and for upward and downward subsurface salt transport.

Recently, the original assumption in ACRUSalinity that the stormflow has the same salinity as that of rainfall was considered inadequate (Idowu, 2007; Thornton-Dibb et al., 2005). Stormflow salinity can vary significantly from rainfall salinity, especially after periods of no rainfall, when the salinity in the soil, mainly near the surface, can increase due to evaporation. When a rainfall event occurs, stormflow comes into contact with the accumulated salts near the surface of the soil and results in a net increase in the salinity of the stormflow, 
causing it to be greater than that of rainfall. In order to account for this, a soil surface layer has been added to ACRUSalinity. The soil surface layer is conceptualised as a thin soil layer that will drain quickly into the A-Horizon (unless the A-Horizon is already wet), and its addition is meant to model the process of stormflow water picking up salts accumulated near the surface of the soil. Salt dissolution, and the resulting stormflow salinity during rainfall, is based on a simplified empirical model developed by Sharpley et al. (1981) to describe the desorption of phosphorus (P) from agricultural soil to runoff. The salt load associated with the intercepted rainfall contributes to the system and is therefore added to the surface layer. This is based on the assumption that the salt load that is deposited on the vegetation as a result of interception is washed down the branches and stems onto the surface layer in a subsequent rainfall event. In addition to the recent inclusion of a soil surface layer to ACRUSalinity, an underground reservoir has been added to ACRU2000 and ACRUSalinity as a representation of underground mined-out areas in coal mining environments (Idowu, 2007). Gains to the underground reservoir comprise groundwater leakages from the surrounding aquifers and the (mine waste) water pumped into the reservoir for storage, while losses are made up of water abstracted from the reservoir (e.g. for irrigation), seepages and spillage when full, as well as controlled releases into the river network through pumping. In the conceptualisation of the underground reservoir, it is assumed that the underground mined-out areas lie below the aquifers and, therefore, that the water in groundwater storage can drain into the underground reservoir. Darcian flow is assumed for the drainage as the level of complexity of the Darcian approach is commensurate with other process representations in ACRU2000 and ACRUSalinity.

\section{Study area}

The study area is part of the Upper Olifants basin, upstream of Witbank Dam, in the Mpumalanga Province of South Africa (Fig. 1). The main land use practices in the basin include coal mining and rain-fed agriculture. The dominant soil types are moderately deep sandy to sandy-clay loams, while the the geology consists of the rocks of the Ecca Group and Dwyka Formation of the Karoo Supergroup (Hodgson and Krantz, 1998). The Ecca Group consists predominantly of sandstone, siltstone, shale and coal, while the Dwyka Group underlies the Ecca and consists of tillite, siltstone and sometimes a thin shale development. Coal mining in the Upper Olifants, by as many as 29 collieries, generates large quantities of low quality minewater and has been recognized as the dominant activity in the Witbank Dam catchment with respect to the pollution and degradation of surface water resources (DWAF, 1993). The study catchment, the Tweefontein Pan catchment, lies for the most part within the Kleinkopje Colliery (Anglo Coal, Witbank, Mpumalanga Province). The catchment has an area of $4.7 \mathrm{~km}^{2}$ and its most noticeable land feature is the Tweefontein Pan, which is a natural surface reservoir to which the surrounding catchment drains. The reservoir is used for storage and evaporation of water pumped from opencast mining areas in the colliery. The capacity and surface area (at maximum capacity) of the reservoir are $4000 \mathrm{M} \ell$ and $1.5 \mathrm{~km}^{2}$, respectively. The typical quality of water in the Tweefontein Reservoir is shown in Table 1. With an electrical conductivity (EC) of 200 to $1000 \mathrm{mS} / \mathrm{m}$ (i.e. 2 to $10 \mathrm{dS} / \mathrm{m}$ ), the water is moderately saline (Rhoades et al., 1992) due to the presence of $\mathrm{SO}_{4}^{2-}, \mathrm{Ca}^{+}$and $\mathrm{Mg}^{2+}$. The water in the Tweefontein Reservoir is the source of

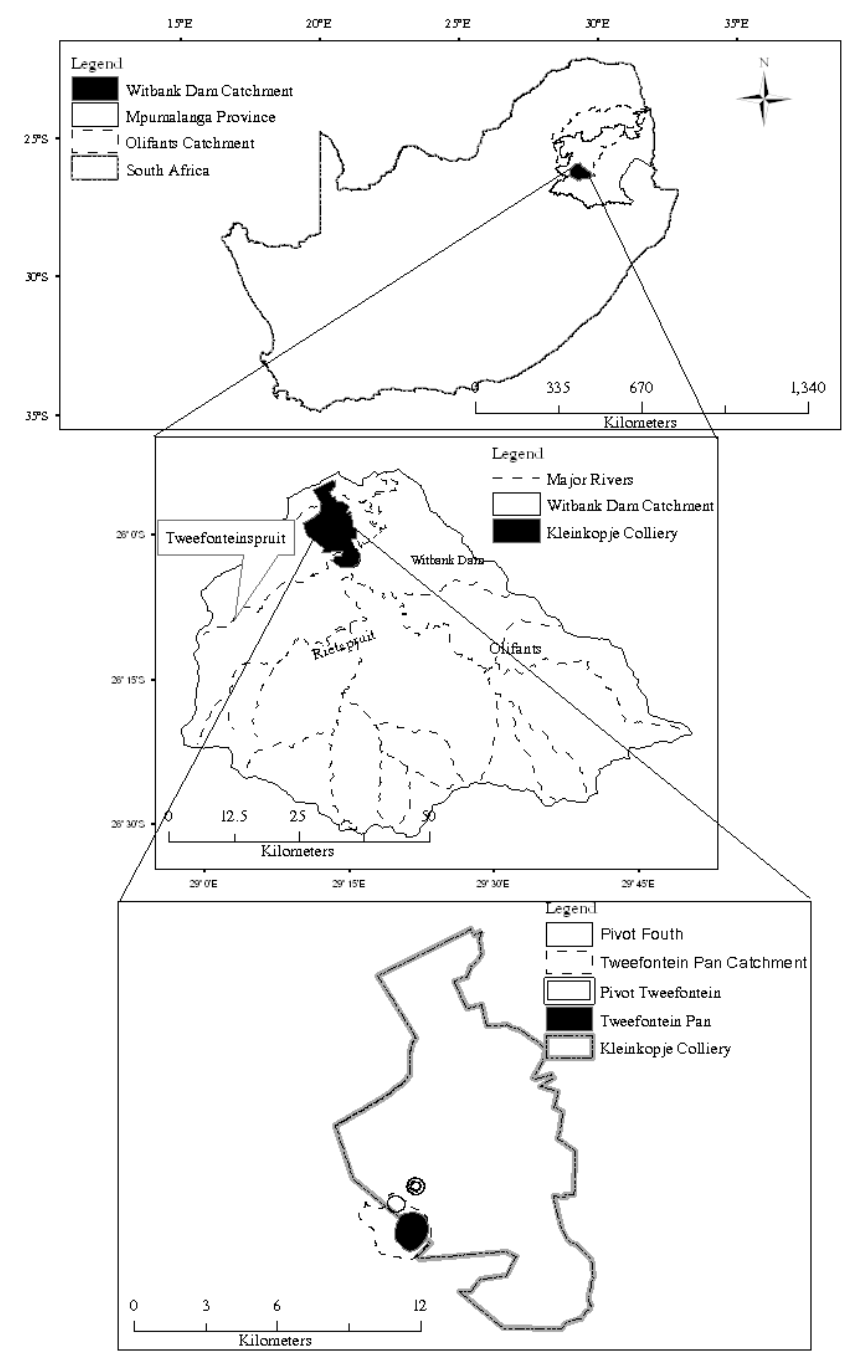

Figure 1

Study area

irrigation water to the Tweefontein centre pivot (20 ha), which is located on rehabilitated soils just outside the catchment. The pivot was rehabilitated with topsoil of varying depth overlying a fill of coal spoil. The spoil was about $40 \mathrm{~m}$ thick, and the average depth to spoil, on the basis of core depths taken on a 40 x 40 m grid, was $0.93 \mathrm{~m}$ (Annandale et al., 2002). In the catchment itself, there is a centre-pivot irrigation system irrigating an undisturbed area of 30 ha (Fourth Pivot) with water from the Tweefontein Reservoir, and an underground reservoir with an estimated capacity of $2000 \mathrm{M} \ell$ and average salinity of $328 \mathrm{mS} / \mathrm{m}$. The underground reservoir comprises old workings of mined-out underground areas in the Tweefontein Pan catchment. An estimated seepage of $2400 \mathrm{~m}^{3} /$ day occurs from the Tweefontein Reservoir into the underground reservoir.

\section{Materials and methods}

The catchment area of the Tweefontein Pan was delineated from digitised orthophotos. An automatic weather station was installed in the catchment to monitor the weather conditions (rainfall, temperature, relative humidity, solar radiation, and wind speed) and the centre-pivot irrigation system in the catchment (Fourth Pivot) was equipped with a tipping bucket rain gauge, which measured the amount and intensity of rainfall and 


\begin{tabular}{|l|c|}
\hline \multicolumn{2}{|c|}{ Table 1 } \\
\begin{tabular}{|} 
Typical irrigation water qualities in \\
Tweefontein Reservoir
\end{tabular} \\
\hline Chemical properties & Values \\
\hline $\mathrm{pH}$ & 8 \\
$\mathrm{EC}(\mathrm{mS} / \mathrm{m})$ & 300 \\
$\mathrm{Ca}^{2+}(\mathrm{mg} / \ell)$ & 420 \\
$\mathrm{Mg}^{2+}(\mathrm{mg} / \ell)$ & 240 \\
$\mathrm{Na}^{+}(\mathrm{mg} / \ell)$ & 32 \\
$\mathrm{Fe}^{2+}(\mathrm{mg} / \ell)$ & 0.08 \\
$\mathrm{Mn}^{2+}(\mathrm{mg} / \ell)$ & 0.01 \\
$\mathrm{Cl}^{-}(\mathrm{mg} / \ell)$ & 8.2 \\
$\mathrm{SO}_{4}^{2-}(\mathrm{mg} / \ell)$ & 1750 \\
$\mathrm{HCO}_{3}^{-}(\mathrm{mg} / \ell)$ & 68 \\
$* \mathrm{SAR}^{2}$ & 0.3 \\
\hline \multicolumn{2}{|c|}{ *Sodium absorption ratio } \\
\hline
\end{tabular}

irrigation. Ceramic cup soil-water samplers for determining the soil-water salinity were installed at a monitoring station within the centre pivot at depths of $0.4,1.0$ and $1.4 \mathrm{~m}$.

Three scenarios were simulated using the available records for 5 years (1999 to 2004). Scenario 1 was the baseline scenario representing the prevailing condition in the Tweefontein Pan catchment. Scenario 2 represented the catchment under widespread irrigation on undisturbed soils, with the mine-water from Tweefontein Reservoir. Scenario 3 represented similar widespread irrigation on a rehabilitated profile.

The observed volume of water in storage in the surface and underground reservoirs at the beginning of the simulation was $3750 \mathrm{M} \ell$ and $1443 \mathrm{M} \ell$, respectively. The land use type identified in the non-irrigated area was categorised as 'veld in poor condition'. In setting up ACRU2000 and ACRUSalinity for the catchment, the interception loss, consumptive water use coefficient and the fraction of the plant roots active in extracting moisture from the soil were dependent on the identified land use type for the non-irrigated area and on maize in the irrigated areas. The soil type identified in the undisturbed part of the catchment was sandy loam. Therefore, the porosity, drained upper limits and permanent wilting point used for the soil type were taken as $0.448,0.189$ and 0.093 , respectively (Schulze et al., 1995b). As the whole catchment was undisturbed, the same soil-water retention values were used for the irrigated and nonirrigated areas. No reliable data were available on the rainfall salinity in the study area. Therefore, an average value of $4 \mathrm{mS} / \mathrm{m}$, as reported for a study of rain water in Johannesburg and environs by the Johannesburg City Council (Blight, 1992), was used. Considering that air pollutants disperse quickly on the Highveld (Blight, 1992), which includes the study area, the value for Johannesburg is not expected to be significantly different from that of the study area

In the baseline simulation of Tweefontein Pan catchment, the amount and quality of water in storage in Tweefontein Reservoir, as well as the salinity of soil-water within the Fourth Pivot, were used for verification. There was no return flow from the pivot into the Tweefontein Reservoir as Tweefontein Pivot was outside the catchment; return flow occurred from the Fourth Pivot only. However, the irrigation water supply to Tweefontein Pivot was abstracted from the Tweefontein Reservoir and therefore included in its water budgeting. For surface reservoir water budgeting in ACRU2000, the following were required: the surface area of the reservoir at full capacity, the surface area to storage volume relationship, as well as the water pumped into or abstracted from the reservoir.

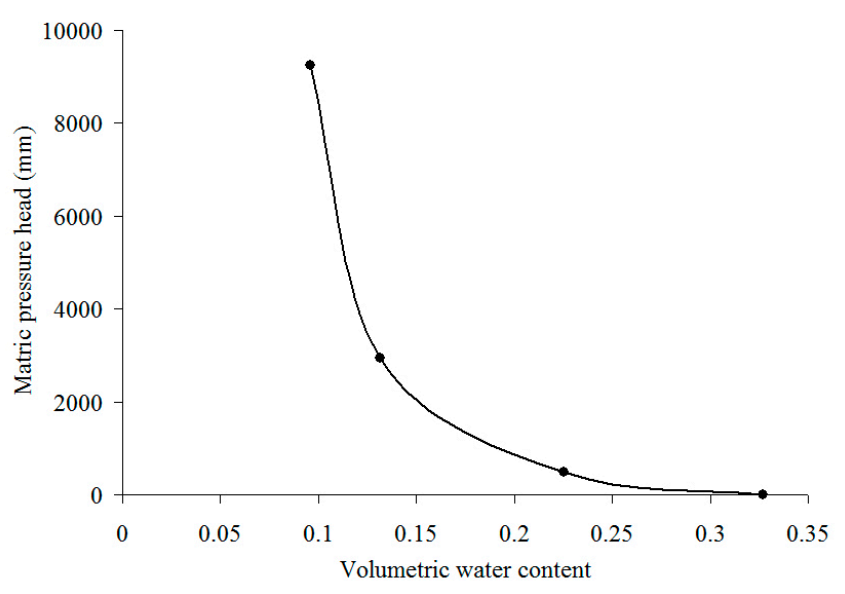

Figure 2

Soil water retention characteristics for Tweefontein Pivot

The surface area to volume relationship for the Tweefontein Reservoir was established from a plot of the data for surface area and volume of water in the reservoir, which yielded the equation:

$$
y=18447 x^{0.2743}
$$

where:

$y$ is the surface area $\left(\mathrm{m}^{2}\right)$;

$x$ is the volume $\left(\mathrm{m}^{3}\right)$;

while 18447 and 0.2743 are the constant and exponent of the surface area:volume relationship respectively (Schulze et al., 1995c).

Both the water abstracted and pumped from opencast mining areas into the reservoir formed part of the ACRU2000 input data for the water and salt budgeting.

Impact of widespread irrigation in the catchment was investigated by increasing the areal extent of the irrigated area (whether undisturbed or rehabilitated) under baseline conditions, in multiples of 20 ha, to the maximum capacity that Tweefontein Pan catchment could provide, while the areal extent of the non-irrigated area was correspondingly reduced. For the simulation of widespread irrigation in undisturbed soils, the hydrodynamic responses verified in the baseline study were employed in setting up ACRU2000 and ACRUSalinity. For the simulation of the widespread irrigation in rehabilitated soils, the responses were those verified in the simulation of Tweefontein Pivot, which was on a rehabilitated profile. The determined porosity, drained upper limit and wilting point of the rehabilitated soil were $0.448,0.2$ and 0.093 , respectively. The pivot was treated as a hydrological system, and to facilitate adequate drainage and monitoring of the runoff from the pivot, waterways were constructed so that runoff could leave the pivot over a weir, where the quantity and quality of runoff were monitored using Campbell logger CR10X and ISCO 3700 portable samplers. Monitoring of the pivot lasted for a year. The details of the monitoring carried out at the pivot and the analyses of the water and salt balances resulting from the simulation have been reported in full in Idowu et al. (2008). In order to adequately simulate the pivot, soil-water retention characteristics (presented in Fig. 2) were determined for the rehabilitated topsoils and subsoils. The simulated runoff volume and salinity were verified using the observed runoff volume and salinity. Comparisons of the observed and simulated runoff volume and salinities are presented in Figs. 3 and 4, respectively. The 


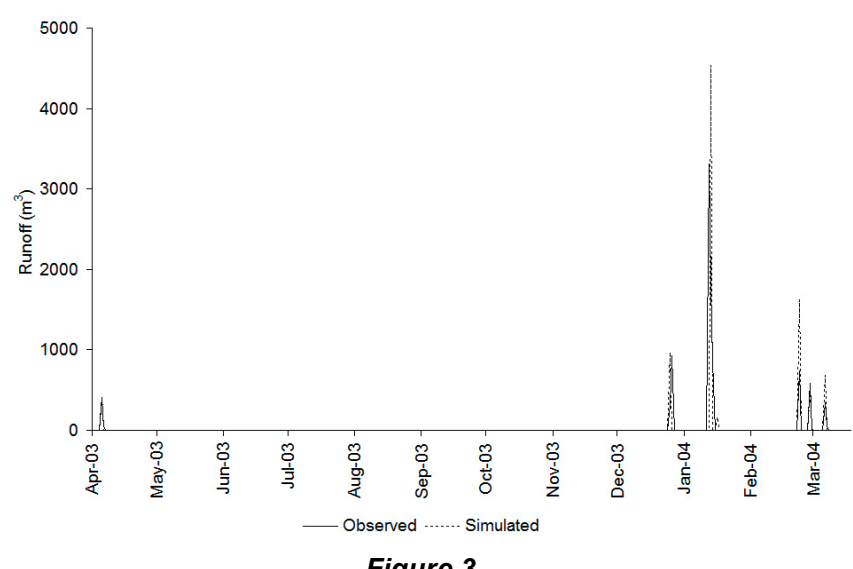

Figure 3

Observed and simulated runoff from Tweefontein Pivot

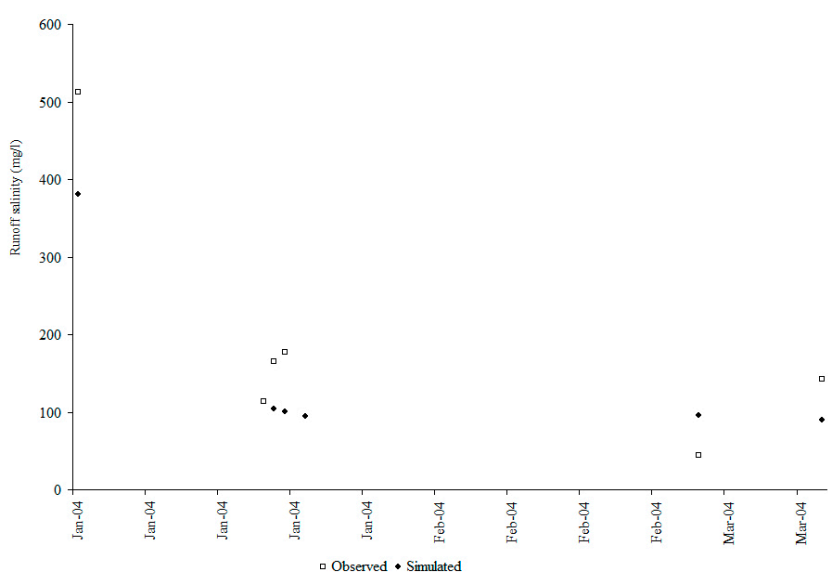

Figure 4

Observed and simulated runoff salinities from Tweefontein Pivot

calculated correlation coefficients of 0.5 and 0.9 , between the simulated and observed runoff volume and salinities indicated that the volume and salinities of runoff from the pivot were simulated well. The water and salt balances obtained from the simulated results of Tweefontein Pivot are presented in Tables 2 and 3.

In investigating the impacts of widespread irrigation with mine-water on rehabilitated soils, a distinction was made between a rehabilitated irrigated area before and after the re-establishment of equilibrium in the water table. Opencast mining leads to dewatering of aquifers and the lowering of the water table, which may form a depression cone not usually extending more than $40 \mathrm{~m}$ in the geologies of the Upper Olifants (Hodgson and Krantz, 1998). The dewatering cone extends over short distances into the adjacent sediments because of shallow mining depths, low hydraulic conductivities and the stratified nature of the Karoo sediments that constitute the aquifers. In the rehabilitated void, water level recovery may occur, with the water level rising to the lowest rehabilitated surface elevation and then decanting, thereby establishing a new equilibrium. Prior to the re-establishment of a new equilibrium, however, percolating water will gradually accumulate in depressions at the bottom of the rehabilitated mined-out area, with the water table gradually rising until a decanting level is reached and equilibrium in the water table is re-established. Consequently, contribution of baseflow to runoff may be insignificant. This is not the case after the re-establishment of equilibrium in the water table, when groundwater will flow in the direction of the hydraulic gradient and contribute to runoff. Taking these into consideration, during the simulations of rehabilitated areas prior to the re-establishment of the water table, the contribution of baseflow to runoff was set at zero, whereas during the simulations representing the period after water table re-establishment, baseflow contributions were driven by the groundwater store and a default decay coefficient $(0.02)$.

\section{Results and discussion}

The observed and simulated volumes, as well as the salinities of water in storage in the Tweefontein Reservoir under baseline conditions, are presented in Figs. 5 and 6. Based on the correlation coefficients between the observed and simulated volumes (0.96) and salinities (0.76) of water in the Tweefontein Reservoir, it can be concluded that the volume and salinity of water in the reservoir were adequately simulated. The decline in water storage in the reservoir was due to evaporation, and due to abstraction of water for irrigation at the Fourth and Tweefontein Pivots, coupled with inconsistent pumping of water into the reservoir. The generally increasing trend in the salinity of water in the reservoir reflected the declining volume of water in the reservoir and the concentration of salts through evaporation. The salinity, which approached $3000 \mathrm{mg} / \ell$, was

Table 2

Water balance of Tweefontein Pivot over a year

\begin{tabular}{|l|c|c|c|c|c|c|c|}
\hline & \multicolumn{2}{|c|}{ Supplied water } & \multicolumn{4}{c|}{ Distribution } \\
\cline { 2 - 8 } & Rainfall & Irrigation & Runoff & $\begin{array}{c}\text { Total } \\
\text { evaporation }\end{array}$ & $\begin{array}{c}\text { Soil } \\
\text { moisture }\end{array}$ & $\begin{array}{c}\text { Groundwater } \\
\text { drainage }\end{array}$ & $\begin{array}{c}\text { Interception } \\
\text { loss }\end{array}$ \\
\hline Volume $\left(\mathrm{m}^{3}\right)$ & 125100.00 & 61130.00 & 8879.04 & 141594.46 & 23218.00 & 6097.80 & 7616.00 \\
\hline Depth $(\mathrm{mm})$ & 625.5 & 305.7 & 44.4 & 708.0 & 116.1 & 30.5 & 38.1 \\
\hline Water distribution $(\%)$ & 67.2 & 32.8 & 4.8 & 76.0 & 12.5 & 3.3 & 4.1 \\
\hline
\end{tabular}

Table 3

Salt balance of Tweefontein Pivot over a year

\begin{tabular}{|c|c|c|c|c|c|c|c|c|c|}
\hline \multirow[t]{3}{*}{ Items } & \multicolumn{2}{|c|}{ Supplied salts } & \multirow{3}{*}{$\begin{array}{c}\text { Generated } \\
\text { salts }\end{array}$} & \multicolumn{6}{|c|}{ Distribution } \\
\hline & \multirow[t]{2}{*}{ Rainfall } & \multirow[t]{2}{*}{ Irrigation } & & \multirow[t]{2}{*}{ Runoff } & \multicolumn{2}{|c|}{ Topsoil } & \multicolumn{2}{|c|}{ Soil surface layer } & \multirow{2}{*}{$\begin{array}{c}\text { Groundwater } \\
\text { drainage }\end{array}$} \\
\hline & & & & & $\begin{array}{l}\text { Precipitated } \\
\text { salts }\end{array}$ & $\begin{array}{l}\text { Dissolved } \\
\text { salts }\end{array}$ & \begin{tabular}{|} 
Precipitated \\
salts
\end{tabular} & $\begin{array}{l}\text { Dissolved } \\
\text { salts }\end{array}$ & \\
\hline Mass (tons) & 3.3 & 117.4 & \multirow[t]{2}{*}{0.3} & 1.1 & 59.8 & 37.9 & 0.00 & -1.4 & 23.25 \\
\hline Mass (\%) & 3.0 & 97.0 & & 1.0 & 49.0 & 31.0 & 0.0 & 0.0 & 19.00 \\
\hline
\end{tabular}

Total available salts $=120.92 t$ 


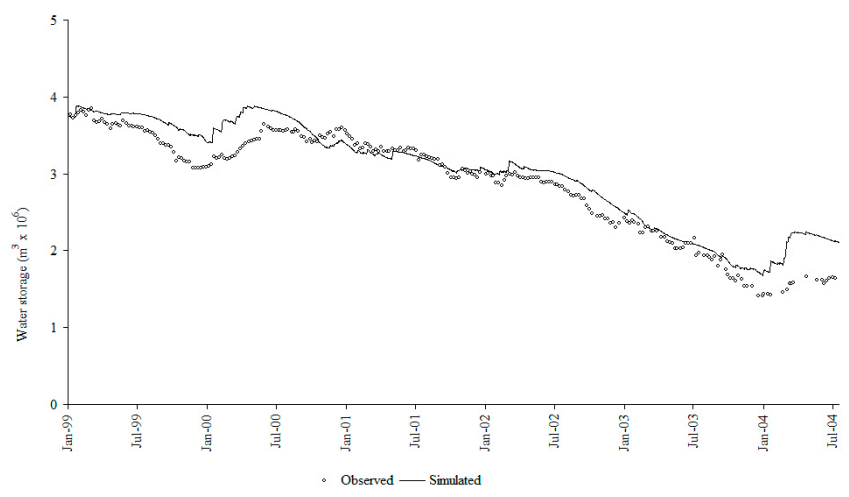

Figure 5

Simulated and observed daily water storage in the Tweefontein Reservoir

within the tolerance levels of maize. The max EC of irrigation water at which growth ceases for maize is $6.7 \mathrm{dS} / \mathrm{m}$ (Ayers and Westcot, 1994), which is about $4300 \mathrm{mg} / \ell$ (Raghunath, 1987). The sharp drop in the salinity of the water towards the end of the simulation (i.e. between January and July 2004) was due to the dilution effect of the increased rainfall which occurred during the period. The rainfall that occurred during this period $(505 \mathrm{~mm})$ was about 4 times that which was recorded for the same period $(125.4 \mathrm{~mm})$ in the previous year.

The comparison of the simulated and observed salinities of water in the irrigated soil at $1 \mathrm{~m}$ at the Fourth Pivot is presented in Fig. 7. The observed data on salinity were irregular because of the difficulties encountered in extracting soil-water with the ceramic soil-water sampler, particularly under dry conditions. The results of the water and salt balance assessment of Fourth Pivot are presented in Tables 4 and 5. Most of the water was lost through evapotranspiration, and the salts were either precipitated within the root zone or associated with the soil-water in the topsoil. Similar assessments for the non-irrigated areas are presented in Tables 6 and 7. The simulated results obtained for the Fourth Pivot were similar to those reported for the same pivot by Annandale et al. (2002) using the Soil Water Balance (SWB) model, which is a mechanistic, daily time-step, soil-water-salt balance, generic crop-growth model. The results from the SWB model, summarised in Table 8 , were based on a study covering a crop season in 1999/00 when the pivot was planted to

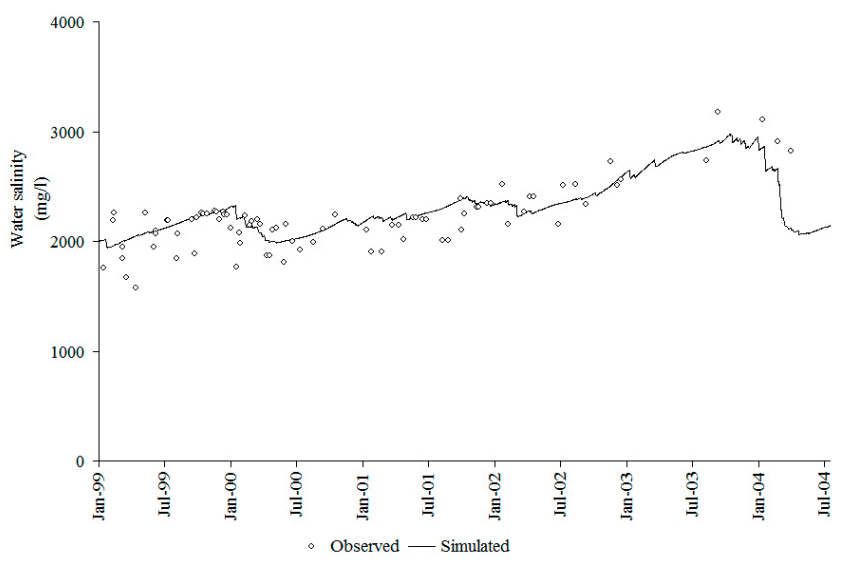

Figure 6

Observed and simulated salinity of water in storage in the Tweefontein Reservoir

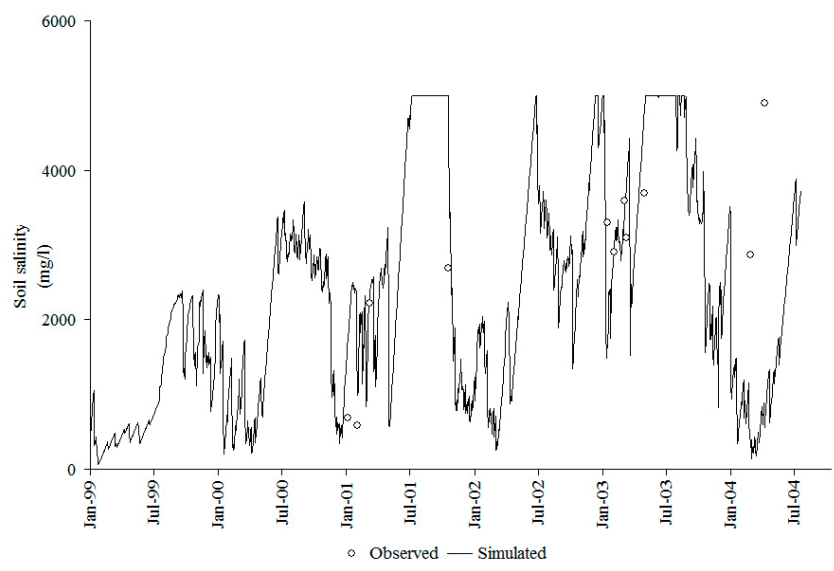

Figure 7

Observed and simulated daily salinities of soil water at $1 \mathrm{~m}$ in the irrigated area of Fourth Pivot

maize. The total evaporation (soil-water evaporation and crop transpiration) and drainage reported for 1999/00 were $71 \%$ and $30 \%$ of the total available water, respectively, while $76 \%$ and $8 \%$ (Table 4 ) were recorded in this study. As the runoff was assumed to be zero by Annandale et al. (2002), the high drainage reported is plausible.

Table 4

Simulated water balance of the irrigated area (Fourth Pivot) in the Tweefontein Pan catchment over 5 years

\begin{tabular}{|l|c|c|c|c|c|c|c|}
\hline \multirow{2}{*}{ Items } & \multicolumn{2}{|c|}{ Supplied water } & \multicolumn{5}{c|}{ Distribution } \\
\cline { 2 - 9 } & Rainfall & Irrigation & $\begin{array}{c}\text { Total } \\
\text { evaporation }\end{array}$ & Stormflow & $\begin{array}{c}\text { Groundwater } \\
\text { drainage }\end{array}$ & $\begin{array}{c}\text { Soil moisture } \\
\text { Interception } \\
\text { loss }\end{array}$ \\
\hline Volume $\left(\mathrm{x} \mathrm{10}^{3} \mathrm{~m}^{3}\right)$ & 749.4 & 662.4 & 1079.4 & 150.3 & 112.2 & 5.7 & 66 \\
\hline Depth $(\mathrm{mm})$ & 2498.0 & 2208.0 & 3598.0 & 501.0 & 374.0 & 19.0 & 220.0 \\
\hline Water distribution (\%) & 53.1 & 46.9 & 76.4 & 10.6 & 7.9 & 0.4 & 4.7 \\
\hline
\end{tabular}

Table 5

\begin{tabular}{|c|c|c|c|c|c|c|c|c|c|}
\hline Sin & ulated s & balance o & pe irrigated & rea (Fourt & $\begin{array}{l}\text { ble } 5 \\
\text { Pivot) in the }\end{array}$ & Tweefonte & Pan catchm & ent over 5 & ars \\
\hline Items & Sup & d salts & Generated & & & Dist & bution & & \\
\hline & Rainfall & Irrigation & & Stormflow & Top & & Soil Surfe & ce Layer & Groundwater \\
\hline & & & & & $\begin{array}{l}\text { Precipitated } \\
\text { salts }\end{array}$ & $\begin{array}{l}\text { Dissolved } \\
\text { salts }\end{array}$ & $\begin{array}{c}\text { Precipitated } \\
\text { salts }\end{array}$ & $\begin{array}{l}\text { Dissolved } \\
\text { salts }\end{array}$ & drainage \\
\hline Mass (tons) & 19.5 & 1601.4 & 2.7 & 126.8 & 757.4 & 290.5 & 0 & 21.8 & 427.1 \\
\hline Mass (\%) & 1.0 & 99.0 & & 7.8 & 46.7 & 17.9 & 0 & 1.3 & 26.3 \\
\hline
\end{tabular}

Total available salts $=1623.6 \mathrm{t}$ 


\begin{tabular}{|c|c|c|c|c|c|c|c|}
\hline \multicolumn{8}{|c|}{$\begin{array}{l}\text { Table } 6 \\
\text { Simulated water balance of the non-irrigated area in the Tweefontein Pan catchment over } 5 \text { years }\end{array}$} \\
\hline \multirow[t]{2}{*}{ Items } & \multicolumn{2}{|c|}{ Supplied water } & \multicolumn{5}{|c|}{$\begin{array}{ll}\text { Distribution } \\
\end{array}$} \\
\hline & Rainfall & Irrigation & $\begin{array}{c}\text { Total } \\
\text { evaporation }\end{array}$ & Stormflow & $\begin{array}{l}\text { Groundwater } \\
\text { drainage }\end{array}$ & Soil moisture & $\begin{array}{c}\text { Interception } \\
\text { loss }\end{array}$ \\
\hline Volume $\left(\mathrm{x} 10^{3} \mathrm{~m}^{3}\right)$ & 11740.6 & 0 & 9494 & 418.3 & 681.5 & 28.2 & 1019.9 \\
\hline Depth (mm) & 2498.0 & 0.0 & 2020.0 & 89.0 & 145.0 & 6.0 & 217.0 \\
\hline Water distribution $(\%)$ & 100.0 & 0.0 & 80.9 & 4.4 & 5.8 & 0.2 & 8.7 \\
\hline
\end{tabular}

\begin{tabular}{|c|c|c|c|c|c|c|c|c|}
\hline \multicolumn{9}{|c|}{$\begin{array}{cc}\text { Table } 7 \\
\text { Simulated salt balance of the non-irrigated area in the }\end{array}$} \\
\hline \multirow[t]{3}{*}{ Items } & \multicolumn{2}{|c|}{ Supplied salts } & \multirow{3}{*}{$\begin{array}{l}\text { Generated } \\
\text { salts }\end{array}$} & \multicolumn{5}{|c|}{ Distribution } \\
\hline & \multirow[t]{2}{*}{ Rainfall } & \multirow[t]{2}{*}{ Irrigation } & & \multirow[t]{2}{*}{ Stormflow } & Topsoil & Subsoil & $\begin{array}{c}\text { Soil surface } \\
\text { layer }\end{array}$ & \multirow[t]{2}{*}{$\begin{array}{l}\text { Groundwater } \\
\text { drainage }\end{array}$} \\
\hline & & & & & $\begin{array}{c}\text { Dissolved } \\
\text { salts }\end{array}$ & $\begin{array}{c}\text { Dissolved } \\
\text { Salts }\end{array}$ & $\begin{array}{l}\text { Dissolved } \\
\text { Salts }\end{array}$ & \\
\hline Mass (tons) & 192.4 & 0.0 & \multirow[t]{2}{*}{2.4} & 27.8 & 12.4 & 28.2 & 19.0 & 106.8 \\
\hline Mass (\%) & 100.0 & 0.0 & & 15.0 & 6.0 & 15.0 & 10.0 & 55.0 \\
\hline
\end{tabular}

Total available salts $=194.8 \mathrm{t}$

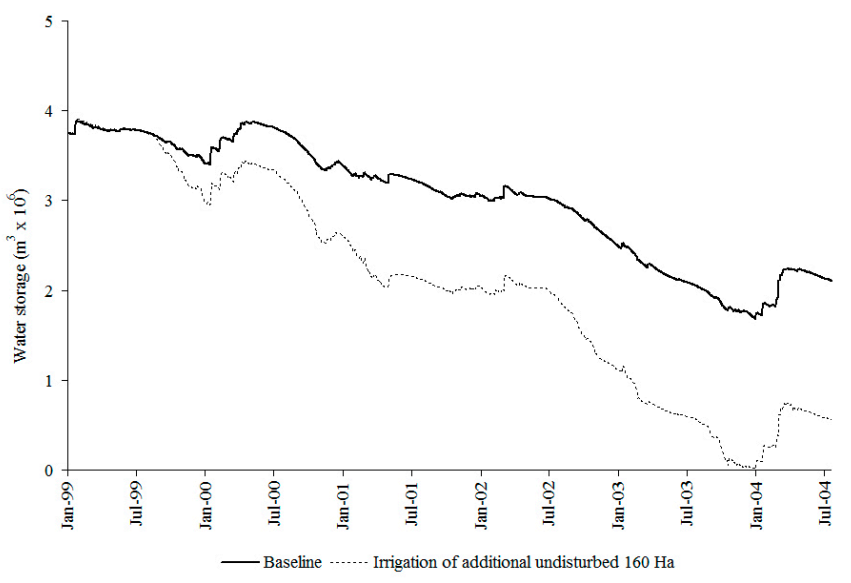

Figure 8

Effect of widespread irrigation of 160 ha in the Tweefontein Pan catchment on the water storage in the Tweefontein Reservoir

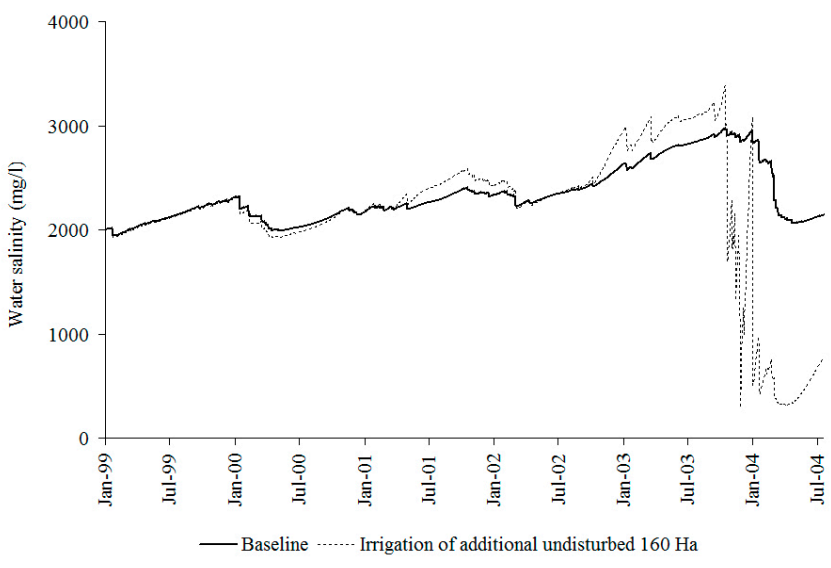

Figure 9

Effect of widespread irrigation of 160 ha in the Tweefontein Pan catchment on the salinity of water in the Tweefontein Reservoir
A comparison of the results from the irrigated and non-irrigated areas indicates that, because of the availability of more salts and water in the irrigated area than in the non-irrigated areas, higher volumes of stormflow, groundwater drainage, soil moisture in the soil horizons and the salt loads associated with them, occurred in the irrigated area than in the non-irrigated area. Similarly, higher average salinities of the runoff (4 480 $\mathrm{mg} / \ell)$ and drainage to groundwater $(824 \mathrm{mg} / \ell)$ were obtained in the irrigated area. The corresponding values in the nonirrigated areas were $556 \mathrm{mg} / \ell$ and $242 \mathrm{mg} / \ell$.

In addition to the irrigation of a rehabilitated area of 20 ha at the Tweefontein Pivot with the water from the Tweefontein Reservoir, simulated results indicated that a further undisturbed area of 160 ha in Tweefontein Pan catchment, representing an additional 8 centre pivots of 20 ha each, could still be sustained without depleting the reservoir. Adequate irrigation of any additional centre pivot will be unsustainable by the water in the reservoir, as this will totally deplete it and have dire consequences for crop growth and yield. Figures 8 and 9 illustrate the effect on the volume and quality of water in the Tweefontein Reservoir through optimum use of the available undisturbed areas for irrigation. The sudden change in the quality of water in the reservoir in comparison to the baseline condition from around October 2003 onwards was due to the increased dilution effect of rainfall with the diminishing water in storage. The results presented in Fig. 8 demonstrate that, in making decisions on widespread irrigation with mine-water, it is very important that sustainability, in terms of the availability of adequate mine-water for widespread application, be assessed.

If Tweefontein Pan catchment was mined out and rehabilitated, and whether the water table had been re-established or not, a maximum of 120 ha could be adequately irrigated on the disturbed profile with mine-water from the reservoir, indicating that a smaller area could be sustained by irrigation with water from the Tweefontein Reservoir than if the catchment had been undisturbed. A comparison of the three scenarios (irrigating an undisturbed area or a rehabilitated area before and after water table re-establishment), regarding the volume and salinity of water in Tweefontein Reservoir, is presented in Figs. 10 and 11 and Table 9. Irrigating a rehabilitated area of 120 ha in Tweefontein Pan catchment (either before or after water table re-establishment) would deplete the water in the reservoir more rapidly than irrigating an undisturbed area of 120 ha (Fig. 10). This is because the runoff (and its salt load) from the rehabilitated area would be lower, and the amount of water 


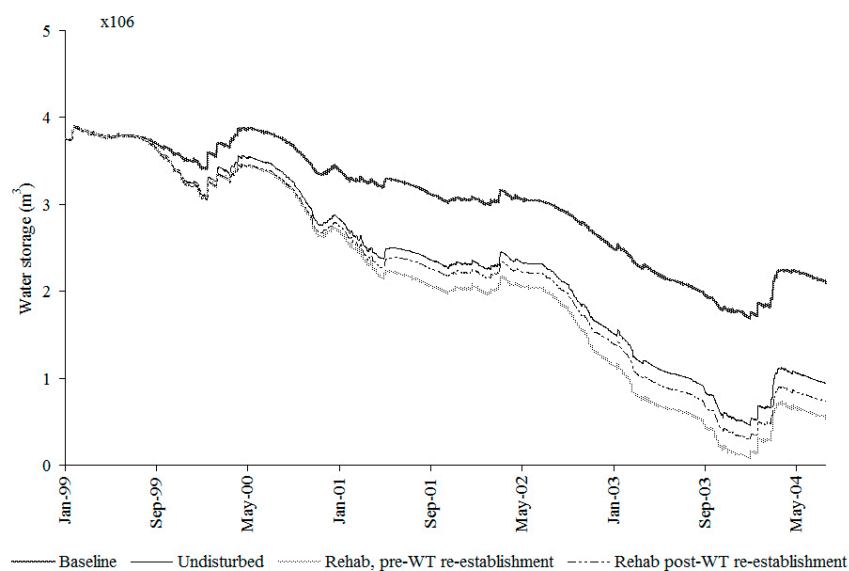

Figure 10

Comparison of the effect of widespread irrigation on the Tweefontein Reservoir water storage, depending on whether the irrigated area of 120 ha is undisturbed or rehabilitated

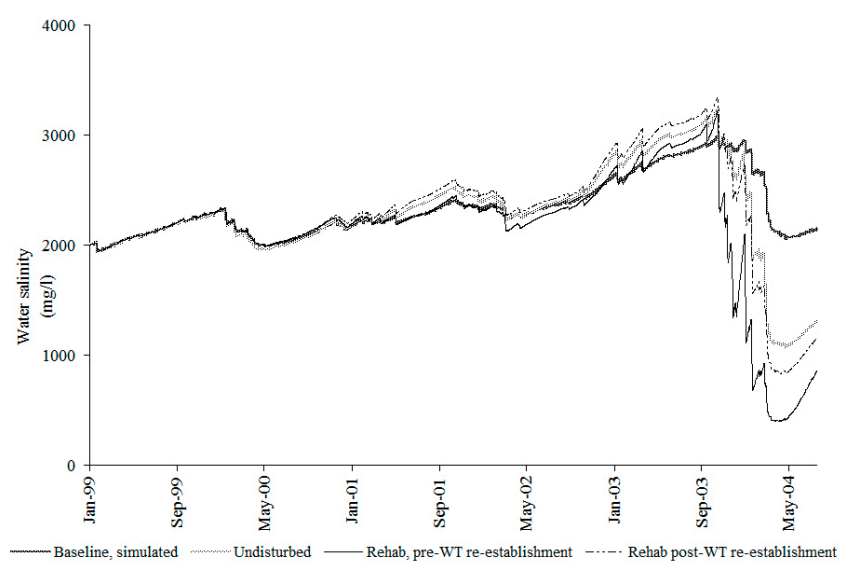

Figure 11

Comparison of the effect of widespread irrigation on the Tweefontein Reservoir water quality, depending on whether the irrigated area of 120 ha is undisturbed or rehabilitated

\begin{tabular}{|l|l|}
\hline \multicolumn{7}{|c|}{ Table 8} \\
Results of simulated soil water balance for maize for the 1999/00 season at the Fourth Pivot using SWB \\
(Annandale et al., 2002)
\end{tabular}

\begin{tabular}{|l|c|c|c|}
\hline \multicolumn{4}{|c|}{ Table 9 } \\
\hline \multicolumn{4}{|c|}{$\begin{array}{c}\text { Comparison of scenario results from widespread irrigation of } \mathbf{1 2 0} \text { ha in the } \\
\text { Tweefontein Pan catchment over 5 years }\end{array}$} \\
\hline Parameters & Undisturbed & $\begin{array}{c}\text { Rehabilitation prior to water } \\
\text { table re-establishment }\end{array}$ & $\begin{array}{c}\text { Rehabilitation after water } \\
\text { table re-establishment }\end{array}$ \\
\hline Runoff (mm) & 744.0 & 195.0 & 490.0 \\
Runoff salt load (t) & 1856.0 & 81.0 & 1678.0 \\
Drainage to groundwater (mm) & 374.0 & 454.0 & 454.0 \\
Drainage to groundwater salt load (t) & 1709.0 & 1982.0 & 1982.0 \\
Baseflow (mm) & 243.0 & 0.0 & 295.0 \\
Baseflow salt load $(\mathrm{t})$ & 1352.0 & 0.0 & 1590.0 \\
Average pan salinity (mg/ $\ell$ ) & 2285.0 & 2143.0 & 2302.0 \\
\hline
\end{tabular}

and salt that would drain into groundwater storage would be greater, when the irrigated area was rehabilitated than when it was undisturbed. Lower runoff (i.e. lower return flow into the pan) means quicker depletion of water in the reservoir. The runoff from the rehabilitated area would be lower before than after water table re-establishment because no contribution from baseflow to runoff would occur prior to water table re-establishment. The salinity of water in the pan would be slightly higher if the irrigated area comprised rehabilitated land after water table re-establishment than when it comprised undisturbed or rehabilitated land prior to water table re-establishment. The volume of groundwater and the accompanying salt load in storage would be highest if irrigation was carried out on rehabilitated soils prior to water table re-establishment.

\section{Conclusion}

The ACRU2000 model and its salinity module, ACRUSalinity, have been realistically applied in the hydrological modelling of the Tweefontein Pan catchment in the Upper Olifants River and enabled a comparative assessment of the surface water and the groundwater resources of the catchment under widespread irrigation with low quality mine-water on undisturbed and rehabilitated soils. Results indicate that widespread irrigation on rehabilitated soils would deplete the source of irrigation water supply in the catchment more rapidly than irrigation on undisturbed soils, due to lower runoff and more drainage into groundwater storage in rehabilitated areas. The same conditions applied to salt loads associated with runoff and drainage to groundwater. This study demonstrates the necessity for adequate integrated assessment of the water resources of the dominant hydrological components in a catchment in which an irrigated area forms a part. This would enable the prediction and management of the volume of water and the mass of salt in the different components resulting from irrigation with low quality mine-water, as well as the likely impact of such irrigation on the quantity and quality of the source of irrigation water supply. 


\section{Acknowledgements}

The authors gratefully acknowledge the financial and technical support of the International Water Management Institute (IWMI), Water Research Commission, and COALTECH2020. The cooperation of Kleinkopje Collieries is also acknowledged.

\section{References}

ANNANDALE JG, JOVANOVIC NZ, BENADE N and TANNER PD (1999) Modelling the long-term effect of irrigation water on soil and water resources. Agric. Ecosyst. Environ. 76 109-119.

ANNANDALE JG, JOVANOVIC NZ, CLAASSENS AS, BENADE N, LORENTZ S, JOHNSTON MA, TANNER PD, AKEN ME and HODGSON FDI (2002) The Influence of Irrigation with Gypsiferous Mine-Water on Soil Properties and Drainage Water. WRC Report No. 858/1/02. Water Research Commission, Pretoria, South Africa.

ANNANDALE JG, JOVANOVIC NZ, HODGSON FDI, USHER BH, AKEN ME, VAN DER WESTHUIZEN AM, BRISTOW KL and STEYN JM (2006) Prediction of the environmental impact and sustainability of large-scale irrigation with gypsiferous minewater on groundwater resources. Water $S A 32$ (1) 21-28.

ANNANDALE JG, JOVANOVIC NZ, PRETORIUS JJB, LORENTZ SA, RETHMAN NFG and TANNER PD (2001) Gypsiferous mine water use in irrigation on rehabilitated opencast mine land: Crop Production, soil water and salt balance. Ecol. Eng. 17 153-164.

AYERS RS and WESCOT DW (1994) Water quality for agriculture. FAO Irrigation and Drainage Paper 29. FAO, Rome, Italy.

BARNARD RO, RETHMAN NFG, ANNANDALE JG, MENTZ W and JOVANOVIC NZ (1998) The Screening of Crop, Pasture and Wetland Species for Tolerance of Polluted Water Originating in Coal Mines. WRC Report No. 582/1/98. Water Research Commission, Pretoria, South Africa.

BELL FG, BULLOCK SET, HALBICH TFJ and LINDSAY P (2001) Environmental impacts associated with abandoned mine in the Witbank Coalfield, South Africa. Int. J. Coal Geol., 45 195-216.

BLIGHT JJ (1992) The Influence of Landfill Covers on the Generation of Leachate. Unpubl. M.Sc. Dissertation, University of the Witwatersrand.

CLARK DJ, KIKER GA and SCHULZE RE (2001) Object-oriented restructuring of the $A C R U$ agrohydrological modelling system. Proc. $10^{\text {th }}$ South African National Hydrological Symposium. 26-28 September 2001, University of Natal, Pietermaritzburg, South Africa.

COLEMAN TJ, ROSSOUW JN and BATH A (2003) A Decision Support System for the Controlled Release of Saline Mine Water during Flood Conditions in the Witbank Dam Catchment. WRC Report No. 900/1/03. Water Research Commission, Pretoria, South Africa.

DWAF (DEPARTMENT OF WATER AFFAIRS AND FORESTRY, SOUTH AFRICA) (1993) Witbank Dam Catchment Quality Management Plan, Pretoria, South Africa.

DIERSCH HG (1988) FEFLOW Reference Manual. Institute for Water Resources Planning and System Research Ltd. Walterdorfer Str. 105, D-12526, Berlin, FRG.

DU PLESSIS HM (1983) Using lime treated acid mine water for irrigation. Water Sci. Technol, 15 145-154.

FERGUSON RI, TRUDGILL ST and BALL J (1994) Mixing and uptake of solutes in catchments: Model development. J. Hydrol. 159 223-233.

GLOBAL WATER PARTNERSHIP (2000) Integrated Water Resources Management. Global Water Partnership Technical Advisory Committee (TAC) Background Papers 4. Global Water Partnership, Stockholm, Sweden.

GROBBELAAR R, USHER B, CRUYWAGEN L-M, DE NECKER E and HODGSON FDI (2004) Long-term Impact of Intermine Flow from Collieries in the Mpumalanga Coalfields. WRC Report No. 1056/1/04. Water Research Commission, Pretoria, South Africa.

HEATH R, MOFFETT M and BANISTER S (2004) Water Related Impacts of Small Scale Mining. WRC Report No. 1150/1/04.

Water Research Commission, Pretoria, South Africa.

HODGSON FDI and KRANTZ RM (1998) Groundwater Quality Deterioration in the Olifants River Catchment above the Loskop Dam with Specialised Investigations in the Witbank Dam Sub-Catchment. WRC Report No. 291/1/98. Water Research Commission, Pretoria, South Africa.

IDOWU OA (2007) Impact of irrigation with gypsiferous mine water on the water resources of subcatchments in the Upper Olifants basin. PhD Thesis, University of KwaZulu-Natal, Pietermaritzburg. 254 pp.

IDOWU OA, LORENTZ SA, ANNANDALE JG, MCCARTNEY MP and JOVANOVIC NZ (2008) Assessment of the impact of irrigation with low quality mine-water on virgin and rehabilitated soils in the Upper Olifants Basin. Mine water Environ. 27 (1) 2-11.

JOVANOVIC NZ, ANNANDALE JG, CLAASSENS AS, LORENTZ SA, TANNER PD (2001) Modeling irrigation with gypsiferous mine-water: a case study in Botswana, Mine-water Environ. 20 $65-72$.

JOVANOVIC NZ, ANNANDALE JG, CLAASSENS AS, LORENTZ SA, TANNER PD, AKEN ME and HODGSON FDI (2002) Commercial production of crops irrigated with gypsiferous mine water. Water $S A 28$ 413-421.

LECLER NL and SCHULZE RE (1995) Irrigation crop water demand. In: Schulze RE (ed.) Hydrology and Agrohydrology: A Text to Accompany the ACRU 3.00 Agrohydrological Modelling System. WRC Report No. TT 69/95: AT17-1 to AT17-18. Water Research Commission, Pretoria, South Africa.

PULLES W, HOWIE D, OTTO D and EASTON J (1995) A manual on mine-water treatment and management practices in South Africa. WRC Report No. TT 80/96. Water Research Commission, Pretoria, RSA.

RAGHUNATH HM (1987) Groundwater. Wiley Eastern Limited, New Delhi, India.

RHOADES JD, KANDIAH A and MARHALI AM (1992) The use of saline water for crop production. FAO Irrigation and Drainage Paper 48. FAO, Rome.

SCHOEMAN JL, MATLAWA SM and HOWARD MD (2002) Quantification of the water balance of selected rehabilitated mine soils under rainfed pastures in Mpumalanga. WRC Report No. 798/1/02. Water Research Commission, Pretoria, South Africa.

SCHULZE RE, AUGUS GR, LYNCH SD and SMITHERS JC (1995a) $A C R U$ : Concepts and structure. In: Schulze RE (ed.) Hydrology and Agrohydrology: A Text to Accompany the $A C R U$ 3.00 Agrohydrological Modelling System. WRC Report No. TT 69/95: AT2-1 to AT2-266. Water Research Commission, Pretoria, South Africa.

SCHULZE RE, ANGUS GR and GUY RM (1995b) Soils. In: Schulze RE (ed.) Hydrology and Agrohydrology: A Text to Accompany the ACRU 3.00 Agrohydrological Modelling System. WRC Report No. TT 69/95: AT5-1 to AT5-40. Water Research Commission, Pretoria, South Africa.

SCHULZE RE, SMITHERS JC, LECLER NL, TARBOTON KC and SCHMIDT EJ (1995c) Reservoir yield analysis. In: Schulze R E (ed.) Hydrology and Agrohydrology: A Text to accompany the $A C R U$ 3.00 Agrohydrological Modelling System.WRC Report No. TT 69/95. AT14-1 to AT14-17. Water Research Commission, Pretoria, South Africa.

SHARPLEY AN, AHUJA LR, YAMAMOTO M and MENZEL RG (1981) The kinetics of phosphorus desorption from soil. Soil Sci. Soc. Am. J. 45 493-496.

TANNER PD, ANNANDALE JG and RETHMAN NFG (1999) Converting problems into opportunities - The use of gypsiferous mine water for crop irrigation. Proc. 22nd Congress. Soil Science Society of South Africa. Pretoria, South Africa.

THORNTON-DIBB SLD, CLARK DJ and LORENTZ SA (2005) The addition of a soil surface layer and corresponding processes 
to ACRUSalinity. Report, School of Bioresources Engineering and Environmental Hydrology, University of KwaZulu-Natal, Pietermaritzburg. 20 pp.

TEWELDEBRHAN AT (2003) The Hydrosalinity Module of $A C R U$ Hydrological Modelling System. Unpubl. M.Sc Thesis, University of KwaZulu-Natal. Pietermaritzburg.
VILJOEN JNJ (1992) Soil development in rehabilitated coal mine spoil: Preliminary observations. $17^{\text {th }}$ Congress Soil Science Society of South Africa. 28-30 January 1992, Stellenbosch, South Africa.

YOUNGER PL (2002) Mine water pollution from Kernow to KwaZuluNatal: Geochemical remedial options and their selection in practice. Scott Simpson Lecture 2002. Geosci. Southwest England (Proc. Ussher Society) 10 255-266. 